\title{
REGIONAL DETERMINANTS OF THE SMALL AND MEDIUM SIZE MANUFACTURING FIRM ENTRY IN A DEVELOPING COUNTRY: EVIDENCE FROM TURKEY
}

\author{
DOI: 10.17261/Pressacademia.2017.445
}

JEFA- V.4-ISS.2-2017(10)-p.154-163

\author{
Mustafa Ozer ${ }^{1}$ \\ ${ }^{1}$ University of Portsmouth, Economics \&Finance Department, England / Kilis Yedi Aralik University, Kilis, Turkey. mustafaozer@kilis.edu.tr
}

\section{To cite this document}

Ozer, M., (2017). Regional determinants of the small and medium size manufacturing firm entry in a developing country: evidence from

Turkey. Journal of Economics, Finance and Accounting (JEFA), V.4, Iss.2, p.154-163

Permemant link to this document: http://doi.org/10.17261/Pressacademia.2017.445

Copyright: Published by PressAcademia and limited licenced re-use rights only.

\begin{abstract}
Purpose- This study investigates regional determinants of the small and medium size firm entry in the manufacturing sector for a developing country, Turkey, in which regional economic development disparities are common.

Methodology- Panel data was collected for the period between 2004 and 2009 and analysed by using Feasible GLS estimation technique. Findings- The results show that entrepreneurship culture, the structure of the industry, industry agglomeration overall are the most important factors stimulating the entry rates. However, the number of patent application as a supply-side variable seems to be the main deterrent of new firm entry by working as a fence in front of new firms. The average wage and low skill labor in labor force are the other factors that negatively influence new firm formation in demand and supply side of the economy.

Conclusion- Some of these regional variables affecting business formation in developed countries have no influence on the small and medium size firm formation in developing countries. This suggests that the determinants could be country specific. Therefore, policy makers should be careful while using evidence from developed countries to stimulate firm start-ups in developing countries.
\end{abstract}

Keywords: New firms; start-ups, regional determinants, regional development, Turkey.

JEL Codes: R10, R58, 012

\section{INTRODUCTION}

Empirical studies in a number of developed countries since 1980, such as in the EU, the USA, and Singapore, have focused on regional determinants of small and medium size firm start-ups as new entries to the sector has been considered more important than existing firms (Reynolds, Storey, \& Westhead, 1994; Pereira, 2004; Zerbinati \& Souitaris, 2005). The reasons are twofold. Firstly, small and medium size new firms have a positive impact on economic growth ${ }^{1}$ as new business is the most likely to grow (Johnson, McMillan, \& Woodruff, 2000; Lingelbach, De La Vina, \& Asel, 2005) and to generate new employment opportunities (Audretsch, Keilbach, \& Lehmann, 2006; McMillan \& Woodruff, 2002). Secondly, every entry of new firms represents a challenge for incumbents which rise competition in the sector and in doing so may generate vital incentives for enhancement (Fritsch \& Falck, 2003).

\footnotetext{
${ }^{1}$ See Ashcroft and Love, (1996); Carree and Thurik (2010); Reynolds et al. (1994); Wennekers and Thurik (1999); Wong, Ho, and Autio (2005).
} 
So far, the literature exploring the effect of regional factors in small and medium size firm start-ups mainly focused on developed countries (See Acs \& Armington, 2004; Audretsch \& Fritsch, 1994; Keeble \& Walker, 1994; Reynolds, 1994). There are limited numbers of studies for developing countries ${ }^{2}$. In their review article, Calá et al. (2017) argue that regional dimension and characteristics affecting small and medium size firm formation substantially differ between develop and developing countries. This study aims to contribute to this literature by investigating regional determinants of firm entry in Turkey $^{3}$. To do this, I use the Feasible GLS estimation method using regional level panel data during the period 2004 to $2009^{4}$. Turkey is an important case study for the following reasons. First, it is a country where significant regional economic disparities are common (Yildiz, Sivri, \& Berber, 2010). Second, economic activities in Turkey were concentrated mostly in highly populated urban areas. This leads high level of migration from rural areas to urban areas which also further raises the regional disparities.

With this in mind, the findings suggest that entrepreneurship culture, the structure of the industry, industry agglomeration are the most important entry-promoting regional factors. But, patenting as a fence appears to be the main deterrent of the small and medium size firm entries. Mean wages and the share of unskilled labor in the labor force are the other factors that negatively influence new entries. The result of this study also indicates that regional determinants might be dependent on the country studied. In particular, there is a difference between developing and developed countries in terms of the factors influencing firm formation. So policy makers should be careful while using evidence from developed countries to stimulate firm start-ups.

The rest of the paper is structured as follows. First, Section 2 reviews the literature. Then, Section 3 describes the data and the methodology. Then in Section 5, the results will be discussed. Lastly, Section 6 gives concluding remarks.

\section{LITERATURE REVIEW}

Following Bosma, Van Stel, and Suddle (2008) regional factors can be divided into four categories: (i) demand and supply variables; (ii) industry agglomeration; (iii) structure of the industry; and (iv) entrepreneurship culture. An expansion in regional market demand for various goods and service are considered as one of the fundamental influences encouraging self-employment (Reynolds, 1994; Reynolds et al., 1994). Consumer demand is usually proxied by population, income and (un)employment measures and these variables are usually defined as levels or growth rates in econometric models (Calá et al., 2016). The composition of the labor force (in terms of age, gender, skills, education and etc.) and capital are the supplyside variables. It is suggested that higher ratio of high skilled labors, measured by college graduates in the population, stimulates business start-ups whereas of unskilled and semi-skilled labors, proxied by high school dropout rates, drops the firm entries (Audretsch \& Fritsch, 1994; Garafoli, 1994; Acs \& Armington, 2002; Fotopoulos \& Spence, 1999). Wage is the cost of hiring a worker for potential entrepreneurs. Higher wages as a supply variable means a higher opportunity cost and a higher cost of hiring a worker which may be expected to deter potential entrepreneurs from starting up a business (Bosma et al., 2008; Fritsch, 1992; Okamuro \& Kobayashi, 2006; Santarelli, Carree, \& Verheul, 2009; Wang, 2006). Moreover, unemployment as a supply-side variable encourages people to start their own businesses as the opportunity cost of being self-employed is likely to decrease for unemployed individuals with low prospects of paid employment (Choi \& Phan, 2006; Davidsson, Lindmark, \& Olofsson, 1994). However, it may also reflect low market demand conditions and unavailability of required capital to be self-employed (Santarelli et al., 2009). The annual number of closed firms in a sector can also be a sign for an inappropriate demand circumstance which deters new entries to the sector (Choi \& Phan, 2006). Garofoli (1994) argues that rich regions in terms of financial assets measured by bank deposits enjoy the easiness of accessibility to capital to start a firm. Previous empirical studies argue that number of patent application measures technological knowledge accumulation on new firm formation (Santarelli et al., 2009; Shane, 1996). However, Choi and Phan (2006) consider patenting as a fence to control knowledge dispersion which deters new entrepreneurs from using analogous knowledge. They, therefore, claim a negative association between new firm formation and patenting.

Industry agglomeration may positively affect the firm start-ups through increasing regional market opportunities and firm's efficiency (Fritsch, Brixy, \& Falck, 2006; Keeble \& Walker, 1994; Reynolds et al., 1994). There exists a huge literature discussing to what extent agglomeration economies exist. It is suggested that the level agglomeration effect may depend on the degree of localization (firms in similar sectors) and urbanization economies (firms in different sectors) (Bosma et al., 2008; Fotopoulos \& Spence, 1999). However, irrespective of the which case appears, agglomeration can make a region less attractive for potential entrepreneurs as if many firms are located close to each other, the price of production factors including wages, land use, etc increases (Arauzo-Carod \& Teruel-Carrizosa, 2005; Nystrom, 2005). In this study, I used two

\footnotetext{
${ }^{2}$ See Calá, Arauzo-Carod, and Manjón-Antolín, (2017) and Calá, Manjón-Antolín, and Arauzo-Carod, (2016) for literature reviews.

${ }^{3}$ Although Günalp and Cilasun (2006) and Ozturk and Kilic (2012) investigate regional determinants of firm formation for the manufacturing sector in Turkey, their empirical strategy, study period, the definition of the dependent variable and most of the regional determinants used in their studies are dissimilar with this paper.

${ }^{4}$ Panel data set only covers the period between 2004 and 2009 as regional entry data regarding Turkish manufacturing industry is not available from 2001 to 2003 and after 2009.
} 
proxies to capture localization economies: (i) Manufacturing sector intensity (Acs \& Armington, 2002, 2004; Bosma et al., 2008; Karlsson \& Backman, 2011); and (ii) gross value added share of manufacturing (Blasco \& Fornielles, 2001). All sector intensity variable captures the effect of urbanization economies on the entry rates (Acs \& Armington, 2002, 2004).

Mason (1991) argues that local business structure measured by average firm size in which heavily dominated by large firms will have a less new firm formation rates. The reasons are twofold. To begin with, small and medium size firms in a sector works as a seedbed for the creation of new and small businesses as employees in these firms easily obtain related experience, abilities, incentives and courage to start up their own business (Blasco \& Fornielles, 2001; Kangasharju, 2000; Keeble \& Walker, 1994). Secondly, the fewer the large firms in a local business sector the lower the barriers to new entries (Acs \& Armington, 2002, 2004).

If being self-employed is encouraged and seemed like a highly respected life by other members of the local society, there exists an entrepreneurship culture in that region, which increase new firm formation (Johannisson, 1984). It is measured by the share of autonomous workers including employers; own account workers and unpaid family workers in labor force (Acs \& Armington, 2002). The higher rate of autonomous workers in a region means higher firm formation rates there.

\section{DATA AND METHODOLOGY}

\subsection{The Dependent Variables: Measures of the Small and Medium Size Firm Formation}

I used a sub-regional panel dataset on annual numbers of the small and medium size firm start-ups for Turkey, identifying 26 sub-regions at IBBS 2 level (or level 2) in a 5-year period (2005-2009). The analysis only covers to the small and medium-sized establishments in manufacturing, the firms with employees less than 200.

Furthermore, an appropriate comparison of numbers of new firm start-ups is not possible without normalization because statistical comparisons of sub-regions with very different size cause measurement bias (Audretsch \& Fritsch, 1994; Fritsch 1992; Kangasharju 2000). Literature suggests two methods for normalization (see Table 1). The first method is, so-called ecological approach, calculates entry rates based on the existing firms. Incumbent firms are the main incubator for new business formation. The second measure is known as the labor force approach, in which annual new firm formation is related to the labour force. This method assumes potential entrepreneurs stem from total labour force which consists of the employees in all sectors plus the unemployed (Acs \& Armington, 2002; Audretsch \& Fritsch, 1994). Using labor force as a denominator is the most frequently preferred standardization technique in the literature as the theory of entrepreneurial choice offered by Evans and Jovanovich (1989) is more consistent with labor force approach. So, I use labor force method in this paper.

Table 1: Dependent Variables Used in Regional Modelling

\begin{tabular}{|l|l|l|}
\hline Variable & Description & Formula \\
\hline NewLab & $\begin{array}{l}\text { The number of new SMEs in } \\
\text { manufacturing per 100.000 } \\
\text { individuals in the labor force. }\end{array}$ & $\begin{array}{l}\text { Annual total number of new SMEs in manufacturing of a } \\
\text { sub-region / total labor force in that sub-region for that } \\
\text { year }\end{array}$ \\
\hline NewEst & $\begin{array}{l}\text { The number of new SMEs in } \\
\text { manufacturing per 100 } \\
\text { establishments }\end{array}$ & $\begin{array}{l}\text { Annual total number of new SMEs in manufacturing of a } \\
\text { sub-region / total number of manufacturing firms in that } \\
\text { sub-region for that year }\end{array}$ \\
\hline
\end{tabular}

\subsection{Sub-Regional Pattern of Firm Formation in Turkey and Economic Development}

Fritsch and Mueller (2006) state that there are a marked path dependency and persistence over time for regional firm entry activity level. In this regard, regions with lower new firm entry rates in the past will expect to have a lower level of new firm formation rates in the near future. This relationship exists for Turkey as well. 
Figure 1. Number of the Small and Medium Size Firms Formation According to Labour Force Approach

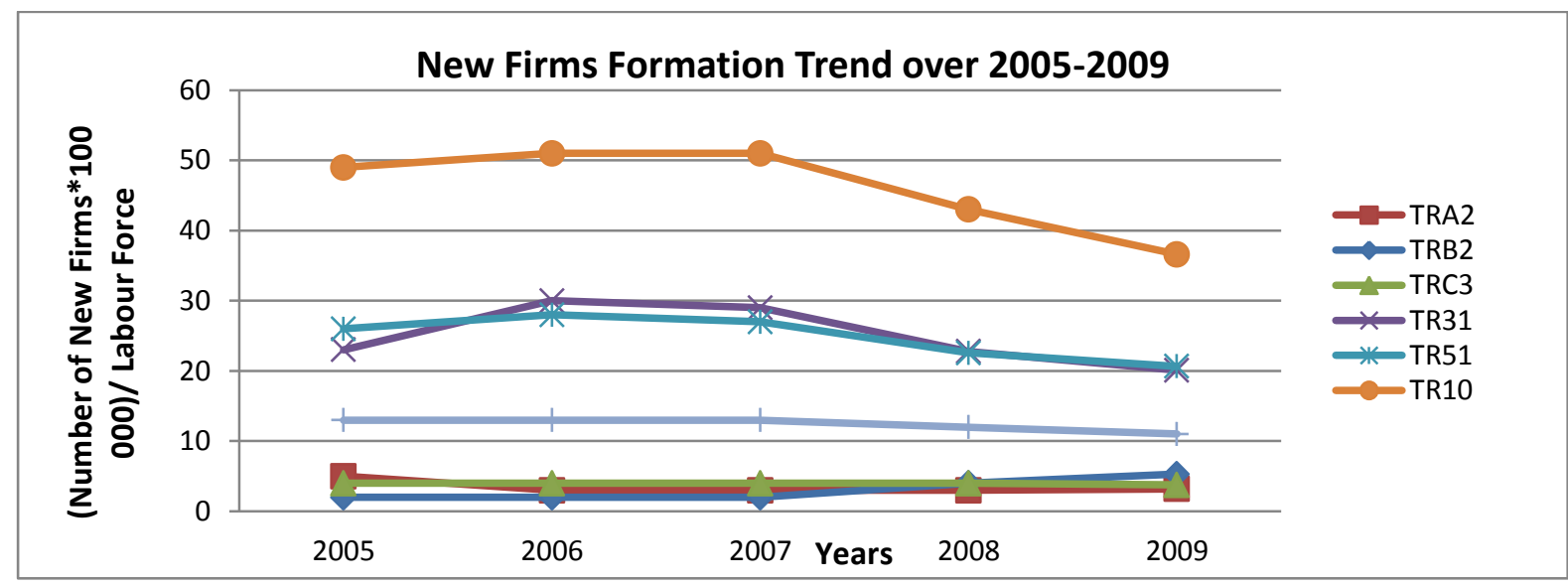

To begin with, the top ranking cities in social and development index (see Yildiz et al., 2010) are in general located in western part of Turkey, whereas the sixteen provinces which are at the bottom of the ranking are located in either eastern or south-eastern part of Turkey. This index is consistent with Figure 1 calculated by labor force approach ${ }^{5}$. The three sub-regions with the highest firm birth rates are simultaneously the most developed sub-regions of Turkey. These are TR10, TR51 and TR31 located in western part of Turkey. However, sub-regions with the least new business formation rates in order are also least developed sub-regions. These are twelve provinces in A2, B2 and C2 sub-regions respectively. In addition to this, the city among all districts with the highest entry rate is Istanbul, which has a population over fifteen million. The gap between the leader Istanbul and its closest follower rate is enormous. Istanbul enjoyed 5 times higher firm birth rates than the closest follower, and about more than 40 times higher than the sub-region with the worst ranking at business formation ${ }^{6}$.

\subsection{Independent Variables}

Sub-district (IBBS2) level data for 13 independent variables (which assumed to have an influence on the entry rates with one-year lag) are collected from three different sources for the years between 2004 and 2008 (See

Table 2: Independent Variables Influencing New Firm Formation Used in the Study

\begin{tabular}{|c|c|c|c|}
\hline Variable $^{a}$ & Formula & Years & Source \\
\hline \multicolumn{4}{|l|}{ Demand and Supply } \\
\hline $\begin{array}{l}\text { PopGrow: population } \\
\text { growth Rate }\end{array}$ & $\frac{(\text { population at } \mathrm{t}-\text { population at } \mathrm{t}-1)}{\text { population at } \mathrm{t}-1} \times 100$ & $2004-2008^{b}$ & TSI \\
\hline $\begin{array}{l}\text { Wage: annual average } \\
\text { wage }\end{array}$ & $\frac{\text { total wage of workforce in manufacturing }}{\text { total number of workers in manufacturing }}$ & $\begin{array}{l}2004,2006 \\
2007,2008^{c}\end{array}$ & TSI \\
\hline $\begin{array}{l}\text { UniGrad: university } \\
\text { graduates rate }\end{array}$ & $\frac{\text { number of university graduates }}{\text { population aged } 25 \text { and over }} \times 100$ & 2004- 2008 & TSI \\
\hline $\begin{array}{l}\text { LowEdu: high school drop } \\
\text { out rate }\end{array}$ & $\frac{\text { number of lower than high school graduartes }}{\text { population aged } 25 \text { and over }} \times 100$ & $2004-2008$ & TSI \\
\hline
\end{tabular}

${ }^{5}$ I constructed another figure by the ecological approach. However, its result was inconsistent with the regional development index as expected. Therefore, it can be said that labor force method fits better in order to explain the dependency of regional variation in the firm formation and economic development. (Unreported graph is available upon request).

${ }^{6}$ Furthermore, Figure 1 clearly indicates that there is a considerable decline in firm start-ups rates started in 2007 for the sub-regions with the highest entry rates. This may be caused by the adverse effects of the subprime mortgage crisis. At first glance, it seems that this can contaminate the results. However, according to Fritsch and Mueller (2006), regional determinants are constant and persistent across time so the effect of the financial crisis on the determinants is not significant. Also, as the primary aim of this study is to explore regional determinants of firm formation, I did not investigate this issue further. 


\begin{tabular}{|c|c|c|c|}
\hline $\begin{array}{l}\text { Unemp: unemployment } \\
\text { rate }\end{array}$ & $\frac{\text { number of unemployed people }}{\text { labour force }} \times 100$ & 2004-2008 & TSI \\
\hline $\begin{array}{l}\text { BankDep: bank deposit } \\
\text { growth rate }\end{array}$ & $\frac{(\text { bank deposits at } t-\text { bank deposits at } t-1)}{\text { bank deposits at } t-1} \times 100$ & $2004-2008$ & BRSA \\
\hline $\begin{array}{l}\text { ClosFrm: closed firm rate in } \\
\text { population }\end{array}$ & $\frac{\text { number of closed firms in manufacturing }}{\text { labour force }} \times 100000$ & $2004-2008$ & TSI \\
\hline $\begin{array}{l}\text { Patent: patent application } \\
\text { Industry Agglomeration }\end{array}$ & $\frac{\text { number of patent application }}{\text { number of firms in manufacturing }} \times 100$ & $2004-2008$ & TPI \\
\hline $\begin{array}{l}\text { GVAShare: gross value } \\
\text { added share }\end{array}$ & $\frac{\text { GVA share of a region in manufacturing }}{\text { total manufacturing GVA }} \times 100$ & $2004-2008$ & TSI \\
\hline $\begin{array}{l}\text { ManFrmInten: } \\
\text { manufacturing firm } \\
\text { intensity }\end{array}$ & $\frac{\text { total number of firm in manufacturing }}{\text { region`s population }} \times 100$ & $\begin{array}{l}2004,2006, \\
2007,2008^{c}\end{array}$ & TSI \\
\hline $\begin{array}{l}\text { AllFrmInten: all sector } \\
\text { intensity } \\
\text { Structure of the Industry }\end{array}$ & $\frac{\text { number of firms }}{\text { region`s population }} \times 100$ & $\begin{array}{l}2004,2006, \\
2007,2008^{c}\end{array}$ & TSI \\
\hline $\begin{array}{l}\text { EstSize: average estimation } \\
\text { size } \\
\text { Entrepreneurship culture }\end{array}$ & $\frac{\text { number of total workers in manufacturing }}{\text { number of total firms in manufacturing }} \times 100$ & $\begin{array}{l}2004,2006, \\
2007,2008^{c}\end{array}$ & TSI \\
\hline $\begin{array}{l}\text { PopEnt: autonomus } \\
\text { workers }\end{array}$ & $\frac{\text { total number of autonomous workers }}{\text { total labour force }} \times 100$ & $2004-2008$ & TSI \\
\hline
\end{tabular}

${ }^{a}$ All variables are at the sub-regional level for a given year

${ }^{b}$ In Turkey, the last census was done in 2000. Later on, starting from 2007, TSI gathered population statistics with address based population registration system. For 2004-2006, missing data related to the population calculated with exponential function method (Durusos, 2005) on the basis of 2000 census.

${ }^{c}$ No observation at 2005. Mean imputation method was used to predict 2005, using the mean of the values at years $t-1$ and $t+1$.

Table 2). These are Turkish Statistical Institute (TSI) Regional Statistics, Banking Regulation and Supervision Agency (BRSA) and Turkish Patent Institute (TPI). As stated before in the introduction section, there are very few regional studies for developing countries related to regional dimensions affecting the entry rates. Therefore, several previous studies for developed countries (e.g. Acs \& Armington, 2002, 2004; Audretsch \& Fritsch, 1994; Garofoli, 1994; Keeble \& Walker, 1994; Reynolds, 1994; Reynolds et al., 1994) were chosen as a reference point in selection and definition process of these independent variables.

\subsection{Econometric Model}

Panel data analysis has been used in the literature to identify regional determinants of the small and medium size firm formation (see Arauzo-Carod \& Teruel-Carrizosa, 2005; Kangasharju, 2000). One of the merits of panel analysis is that it allows us to account for heterogeneity across sub-regions, for dynamic impacts that are not noticeable in cross-section analysis, and the correlation within the regions (Greene, 2011). Another advantage is that panel data allows us to control explanatory variables which are unobservable but correlated with observed independent variables including social and cultural factors assumed to be constant over time (Schmidheiny, 2012). Since the development data set consists of 26 subregions, I hypothesized that these regions are different than each other and these differences should be represented in the analysis. However, fixed effect model in panel analysis accepts that the variance across regions is zero. To test this hypothesis, I applied Breusch and Pagan Lagrangian Multiplier (LM) test in which the null hypothesis is that the variance across groups is 0 . Since the $p$-value for the LM test is smaller than 0.001 (see Table 3 for the test results) I reject the null hypothesis and conclude that there are significant differences across regions. These differences are reflected with random intercepts $\left(u_{i}\right)$, but the effect of independent variables on the outcome will be assumed to be constant for different regions. As a result, I used here the analysis of panel data with random intercept. The data set consists of 130 observations of 26 sub-regions from 5 consecutive years. 
The panel data analysis with random intercepts is formulated as:

$Y_{i t}=\alpha+\sum_{k=1}^{p} \beta_{k} X_{k i(t-1)}+u_{i}+\varepsilon_{i t}$,

(Model 1)

where $Y_{i t}$ is the dependent variable for the $\mathrm{i}^{\text {th }}$ group at time $\mathrm{t}$, with the corresponding $\mathrm{k}^{\text {th }}$ independent variable $X_{i t k}$ $\left(\mathrm{k}=1, \ldots, \mathrm{p}\right.$ and $\mathrm{p}$ is the number of independent variables). Model 1 specifies that $u_{i}$ is a group-specific random effect (i.e. random intercept), and $\varepsilon_{i t}$ is the residual error of each observation. $\alpha$ is the common intercept term, and $\beta_{k}$ is the fixed effect of the corresponding independent variable. Moreover, in this study, in accordance with the previous literature, the new firm formation rates in a certain year $(t)$ regressed on the independent variables from the previous year $(t-1)$.

As the outcome variable is continuous, panel data analysis assumes a linear relationship between the outcome and the independent variables. The independent variables ClosFrm, GVAShare, EstSize, Wage, UniGrad, and Unemp are far from satisfying this assumption. Therefore, I took the logarithm of the outcome and these independent variables. Also, I tested collinearity issue between independent variables. There is no severe collinearity problem since only a few pairwise correlations between independent variables exceed 0.80 and collinearity may cause some problems if there are many pairwise correlations more than 0.80 or 0.90 (Franke, 2010). Fixed effects models with random intercepts already accept that the residuals are not independent and identically distributed. However, I still carried out Wald test for heteroscedasticity of residuals (see Table 3 for the test results). The null is homoscedasticity (or constant variance). I reject the null with a p-value less than 0.05 and conclude heteroscedasticity of error terms. To address this problem, robust standard errors of the parameter estimates were used. Finally, the normality of fitted residuals was checked and they did not show any departure from normality ${ }^{7}$. Eventually, I used Feasible GLS estimation technique and the analysis was carried out in Stata 12.0. The final model is:

$\operatorname{logNewLab}{ }_{i t}=$

$\beta_{0}+\beta_{1} \log$ ClosedFrm $_{i t-1}+\beta_{2} \operatorname{logGVAShare~}_{i t-1}+\beta_{3} \log _{\text {EstSize }}$ It $-1_{1}+\quad \beta_{4} \operatorname{logWage}_{i t-1}+$ $\beta_{5} \log$ UniGrad $_{i t-1}+\beta_{6}$ BlogUnemp $_{i t-1}+\quad \beta_{7}$ ManFrmInten $_{i t-1}+\beta_{8}$ AllFrmInten $_{i t-1}+$ $\beta_{9}$ Pop $_{\text {row }}+1+\beta_{10}$ Patent $_{i t-1}+\beta_{11}$ BankDep $_{i t-1}+\beta_{12}$ LowEdu $_{i t-1}+\beta_{13}$ PopEnt $_{i t-1}+u_{i}+\varepsilon_{i t}$

(Model 2)

\section{FINDINGS AND DISCUSSIONS}

The result of panel data analysis is demonstrated in Table 3. Absolute $z$ values are indicated in brackets. The effect of the log transformed variables can be interpreted in terms of the impact of percentage change on the dependent variable, and the effect of non-transformed variables can be interpreted as the impact on the change in the logarithm of the outcome.

I start presenting the results with demand and supply variables. Although previous studies show that there is a strong positive effect of population growth rates (PopGrow) on new firm formation rates (Acs \& Armington, 2002, 2004; Audretsch \& Fritsch, 1994; Bosma et al., 2008, Davidsson et al., 1994; Keeble \& Walker, 1994; Okamura \& Kobayashi, 2006; Reynolds, 1994), this paper finds no significant effect of PopGrow. The possible reason could be that one-year lag may be insufficient as Bosma et al. (2008) suggests using two-year lag periods. Unemployment rates (LogUnemp) have also an insignificant effect on new firm formation. Similarly, lag periods might be also insufficient to measure the impact of unemployment. Van Stel and Suddle (2008) argue that the effect of unemployment on new business entry is subject to at least six year lag periods. However, LogWage has a significant negative effect on new firm formation as expected. This is consistent with previous studies (See Bosma et al., 2007; Fritsch, 1992; Okamura \& Kobayashi, 2006; Santarelli et al., 2009; Wang, 2006).

Moreover, similarly to Audretsch and Fritsch (1994) and Garofoli (1994) findings, high school dropout rates (LowEdu) as a proxy for low skilled labors in labor force affect new firm formation negatively. No evidence was found that business startups are influenced by university graduate rates (LogUnigrad), similar to the other studies in the literature (Acs \& Armington, 2002; Garofoli 1994). Acs and Armington (2002) propose two potential reasons; (i) a rise in university graduate rates are effective for all other sectors but not for manufacturing; and (ii) share of technical and managerial qualification in labour force could be a better representative of skilled labours in labour force than university graduates. This is because not all university graduates have proper skills and experience to run a firm, whereas managers and technical personals in a firm can learn better both necessary technical production process and other necessary staff to run a business. However, it is impossible to obtain related data for these indicators for the analysis periods at the regional level.

In the literature, Garofoli (1994) have found a positive influence of deposits growth rates (BankDep) on the firm formation. However, this paper finds no evidence for this relationship. This might be caused by the following reasons: First, the reason could be low capital requirements of the small and medium size firms in Turkish manufacturing industry. The second reason could be recent government subsidies for potential entrepreneurs in Turkey. For instance, if an entrepreneur wants to open

\footnotetext{
${ }^{7}$ The results of unreported test statistics for assumptioıns are available upon request.
} 
a business in a rural area, 65 percent of all expenditures can be met by the government (Kobi-Line, 2012). Third, annual interest rates fell from 110 percent in 2000 to 18 percent in 2009 and still continues to fall (Central Bank of the Republic of Turkey, 2012). Therefore, bank loan has become another alternative to funding business start-ups. Overall, above reasons all together facilitated and diversified potential source to acquire financial capital for entrepreneurs. However, it is hard to collect data for these variables at the regional level. Finally, the number of patent application (Patent) measuring technological capital level in that region has the highest negative significant effect on business start-ups rates. The potential reason could be that patenting as a fence prevents knowledge diffusion which discourages potential entrepreneurs entering the market (Choi \& Phan, 2006).

All industry agglomeration variables have significant positive effects on new firm formation. Gross value added share variable (LogGVAShare), with a positive coefficient around 0.16 , is the variable with the highest positive impact. These results overall support incubator theory stating that industry agglomeration positively contributes new firm formation by increasing the supply of knowledge spillovers, workers with related skills, and a number of raw material and interim goods suppliers. Furthermore, considering that these effects measured with localization and urbanization economies, it could be argued that the benefits of urbanization and localization economies in Turkish sub-regions are likely to suppress the negative effects of them.

Table 3: FGLS Estimates of the Determinants of the Small and Medium Size Firm Formation (dependent variable is the LogNewLab) ${ }^{8}$

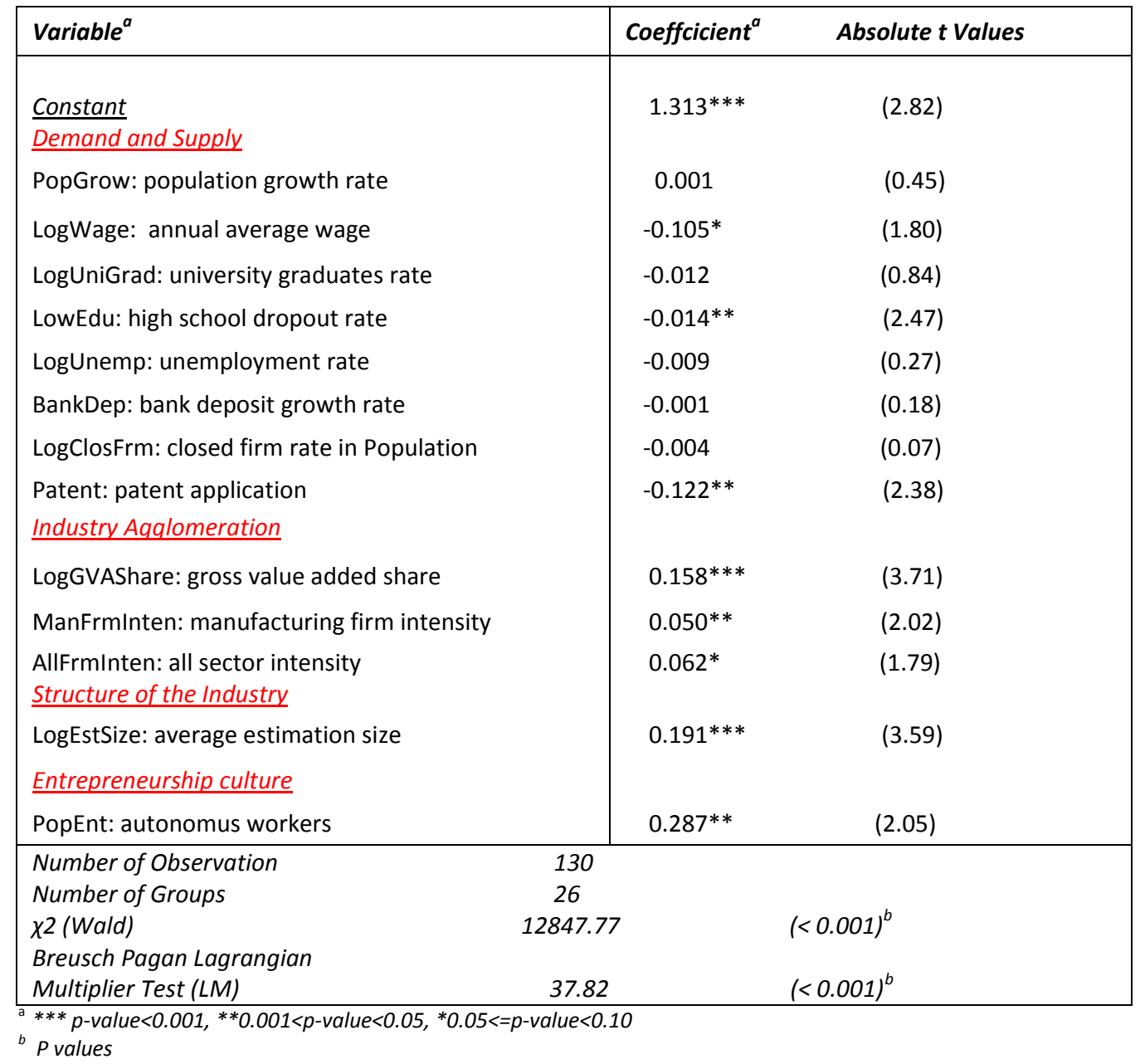

Surprisingly, mean establishment size (LogEstSize) measuring the structure of the industry has a significant positive impact with a coefficient around 0.19. Sutaria and Hicks (2004) offer two potential explanation for the results. First, large firms

\footnotetext{
${ }^{8} \mathrm{I}$ also estimated Model 2 by ecological approach. The results of ecological approach differs from labour force approach as expected because of the reasons discussed earlier in Section 3.1 (the results are available upon request).
} 
trigger the development of new interim goods suppliers of that industry. The interdependence between small and large firms for a number of goods and service also grows as mean establishment size grows. This is because production is a long time-consuming process. However, not all steps of the production line are profitable for one firm. Second, large businesses not only cause an extension in the base of suppliers but also generate a stable business atmosphere for small firms in which they can become prosperous.

Entrepreneurship culture proxied by autonomous workers (PopEnt) in labor force seem to be the most important factors, with the highest positive and significant coefficient (around 0.29), for new firm formation. This is not surprising as a region with a high percentage of autonomous workers in population means that ownership of a business is a preferred lifestyle, which promotes new firm formation rates (Johannisson, 1984; Acs \& Armington, 2002).

\section{CONCLUSION}

This paper explores regional variation in the small and medium size business start-ups in the manufacturing sector in developing countries using Turkey, in which regional economic development disparities are common, as an illustrative case. First of all, this study shows a considerable disparity in business formation rates across regions, however much less variation over time (at least during the analysis period). To examine regional determinants further, I also provide estimates from Feasible GLS estimation technique which use regional level panel data during the period 2004 to 2009. The findings indicate that entrepreneurship culture, the structure of the industry, industry agglomeration are the most significant determinants encouraging new firm start-ups. Nevertheless, patenting as a fence appears to be the main deterrent of the new entry. Mean wages and the share of unskilled labor in labor force are the other factors that negatively influence new firm formation. It is worth noting that the explanatory variable choice of this study was based on the previous extensive literature on developed countries. It seems that some of the regional variables affecting business formation in developed countries have no influence on the small and medium size firm formation in developing countries. This suggests that the determinants could be country specific. Since policy makers use evidence from developed countries to encourage new firm formation, the findings of this study cast doubt on the validity of such evidence when applied to developing countries. Finally, there are of course some shortcomings of this study. It only analyses manufacturing sector. Future research should take other sectors into account.

\section{REFERENCES}

Acs, Z. J., \& Armington, C. (2004). The impact of geographic differences in human capital on service firm formation rates. Journal of Urban Economics, 56(2), 244-278.

Arauzo-Carod, J. M., \& Teruel-Carrizosa, M. (2005). An Urban Approach to Firm Entry: The Effect of Urban Size. Growth and Change, 36(4), 508-528.

Ashcroft, B. \& Love J. H. (1996). Employment Change and New Firm Formation, in UK Countries 1981-89. In M. W. Danson (Ed.), Small Firm Formation and Regional Economic Development. London: Routledge Studies in Small Business.

Audretsch, D. B., \& Fritsch, M. (1994). The geography of firm births in Germany. Regional studies, 28(4), 359-365.

Audretsch, D. B., Keilbach, M. C. \& Lehmann, E. E. (2006). Entrepreneurship and Economic Growth. New York, NY USA: Oxford University Press

Banking Regulation and Supervision Agency.(2012, July 26). BRSA Main Page.Retrieved from http://www.bddk.org.tr/Websitesi/English.asp

Baptista, R., Escária, V., \& Madruga, P. (2008). Entrepreneurship, regional development and job creation: the case of Portugal. Small Business Economics, 30(1), 49-58.

Blasco, A. S., \& Fornieles, M. R. C. (2001). Geographical determinants of the creation of manufacturing firms: The regions of Spain (No. 68). Universitat de Barcelona. Espai de Recerca en Economia.

Bosma, N., Van Stel, A., \& Suddle, K. (2008). The geography of new firm formation: Evidence from independent start-ups and new subsidiaries in the Netherlands. International Entrepreneurship and Management Journal, 4(2), 129-146.

Calá, C. D., Arauzo-Carod, J. M., \& Manjón-Antolín, M. (2017). Determinants of New Firm Formation in Developing Countries: A Review. International Review of Entrepreneurship, 15(1).

Calá, C. D., Manjón-Antolín, M., \& Arauzo-Carod, J. M. (2016). Regional determinants of firm entry in a developing country. Papers in Regional Science, 95(2), 259-279.

Carree, M. A., \& Thurik, A. R. (2010). The impact of entrepreneurship on economic growth. In Handbook of entrepreneurship research (pp. 557-594). Springer New York. 
Central Bank of the Republic of Turkey (2012, October 4). TCMB Main Page. Retrieved from http://www.tcmb.gov.tr/yeni/eng/.

Choi, Y. R., \& Phan, P. H. (2006). The influences of economic and technology policy on the dynamics of new firm formation. Small Business Economics, 26(5), 493-503.

Davidsson, P., Lindmark, L., \& Olofsson, C. (1994). New firm formation and regional development in Sweden. Regional Studies, 28(4), 395410.

Durusoy, R. (2005). Population Projection Methods, Department of Public Health Seminar Program. Izmir: Ege University.

Evans, D. S., \& Jovanovic, B. (1989). An estimated model of entrepreneurial choice under liquidity constraints. Journal of political economy, 97(4), 808-827.

Franke, G. R. (2010). Multicollinearity. Wiley International Encyclopedia of Marketing.

Fritsch, M. (1992). Regional differences in new firm formation: evidence from West Germany. Regional Studies, 26(3), $233-241$.

Fritsch, M., Brixy, U., \& Falck, O. (2006). The effect of industry, region, and time on new business survival-a multi-dimensional analysis. Review of industrial organization, 28(3), 285-306.

Fritsch, M., \& Falck, O. (2003). New firm formation by industry over space and time: A multi-level analysis (No. 322). DIW Discussion Papers.

Fritsch, M., \& Mueller, P. (2006). The evolution of regional entrepreneurship and growth regimes. In Entrepreneurship in the region (pp. 225-244). New York: Springer.

Fotopoulos, G., \& Spence, N. (1999). Spatial variations in new manufacturing plant openings: Some empirical evidence from Greece. Regional Studies, 33(3), 219-229.

Garofoli, G. (1994). New firm formation and regional development: the Italian case. Regional studies, 28(4), $381-393$.

Greene, W.H. (2011). Econometric Analysis. (7 $7^{\text {th }}$ ed). New York University: Pearson Prentice Hall.

Günalp, B., \& Cilasun, S. M. (2006). Determinants of entry in Turkish manufacturing industries. Small Business Economics, 27(2), $275-287$.

Johannisson, B. (1984). A Cultural Perspectives on Small Business-Local Business Climate. International Small Business Journal, 2(4), $32-43$.

Johnson, S., McMillan, J., \& Woodruff, C. (2000). Entrepreneurs and the ordering of institutional reform: Poland, Slovakia, Romania, Russia and Ukraine compared. Economics of Transition, 8(1), 1-36.

Kangasharju, A. (2000). Regional variations in firm formation: Panel and cross-section data evidence from Finland. Papers in Regional Science, 79(4), 355-373.

Karlsson, C., \& Backman, M. (2011). Accessibility to human capital and new firm formation. International Journal of Foresight and Innovation Policy, 7(1-3), 7-22.

Keeble, D., \& Walker, S. (1994). New firms, small firms and dead firms: spatial patterns and determinants in the United Kingdom. Regional studies, 28(4), 411-427.

Kobi-Line Support Centre. (2012, October 4). Kobi-Line Home Page. Retrieved from http://www.kobi-line.com.

Lingelbach, DC, De La Vina, L \& Asel, P (2005). What's Distinctive about Growth-Oriented Entrepreneurship in Developing Countries? (Center for Global Entrepreneurship). San Antonio, Texas: UTSA College of Business.

Mason C. (1991) Spatial Variations in Enterprise: The Geography of New Firm Formation. In R. Burrows (Ed.), Deciphering the Enterprise Culture: Entrepreneurship, Petty Capitalism and the Restructuring of Britain (pp. 74-106). New York: Routledge.

McMillan, J., \& Woodruff, C. (2002). The central role of entrepreneurs in transition economies. The Journal of Economic Perspectives, 16(3), 153-170.

Nystrom, K. (2005), Determinants of Regional Entry and Exit in Industrial Sectors. (CESIS No. 33).

Okamuro, H., \& Kobayashi, N. (2006). The Impact of Regional Factors on the Start-Up Ratio in Japan. Journal of Small Business Management, 44(2), 310-313.

Ozturk, S., \& Kilic, C. (2012). Patterns and determinants of entry and exit in Turkish manufacturing industries. International Journal of Arts and Commerce, 1(5), 107-118.

Pereira, A. A. (2004). State entrepreneurship and regional development: Singapore's industrial parks in Batam and Suzhou. Entrepreneurship \& Regional Development, 16(2), 129-144.

Reynolds, P. (1994). Autonomous firm dynamics and economic growth in the United States, 1986-1990. Regional Studies, 28(4), 429-442.

Reynolds, P., Storey, D. J., \& Westhead, P. (1994). Cross-national comparisons of the variation in new firm formation rates. Regional Studies, 28(4), 443-456. 
Santarelli, E., Carree, M., \& Verheul, I. (2009). Unemployment and firm entry and exit: an update on a controversial relationship. Regional Studies, 43(8), 1061-1073.

Schmidheiny, K. (2012). Short Guides to Microeconometrics. Panel Data: Fixed and Random Effects. Basel: Universitat Basel.

Shane, S. (1996). Explaining variation in rates of entrepreneurship in the United States: 1899-1988. Journal of Management, 22(5), 747781.

Sutaria, V., \& Hicks, D. A. (2004). New firm formation: Dynamics and determinants. The Annals of Regional Science, 38(2), $241-262$.

Turkish Patent Institute. (2012, July 26). TSI Patent Statistics. Retrieved from http://www.tpe.gov.tr/portal/default2.jsp?sayfa=139.

Turkish Statistical Institute. (2012, July 25). TSI Regional Statistics. Retrieved from http://tuikapp.tuik.gov.tr/Bölgesel/menuAction.do?dil $=e n \#>$.

Van Stel, A., \& Suddle, K. (2008). The impact of new firm formation on regional development in the Netherlands. Small Business Economics, 30(1), 31-47.

Wennekers, S., \& Thurik, R. (1999). Linking entrepreneurship and economic growth. Small business economics, 13(1), 27-56.

Wang, S. W. (2006). Determinants of new firm formation in Taiwan. Small Business Economics, 27(4), 313-321.

Wong, P. K., Ho, Y. P., \& Autio, E. (2005). Entrepreneurship, innovation and economic growth: Evidence from GEM data. Small business economics, 24(3), 335-350

Yildiz, E.B., Sivri, U. \& Berber, M. (2010, October). Socio-Economic Development Ranking of Provinces in Turkey. In proceeding of International Regional Development Symposium (pp.693-705).

Zerbinati, S., \& Souitaris, V. (2005). Entrepreneurship in the public sector: a framework of analysis in European local governments. Entrepreneurship \& regional development, 17(1), 43-64. 